Prepared for the U.S. Department of Energy

under Contract DE-AC05-76RL01830

\title{
Radiation Doses to Hanford Workers from Natural Potassium-40
}

DJ Strom

TP Lynch

DR Weier

February 2009 


\title{
DISCLAIMER
}

This report was prepared as an account of work sponsored by an agency of the United States Government. Neither the United States Government nor any agency thereof, nor Battelle Memorial Institute, nor any of their employees, makes any warranty, express or implied, or assumes any legal liability or responsibility for the accuracy, completeness, or usefulness of any information, apparatus, product, or process disclosed, or represents that its use would not infringe privately owned rights. Reference herein to any specific commercial product, process, or service by trade name, trademark, manufacturer, or otherwise does not necessarily constitute or imply its endorsement, recommendation, or favoring by the United States Government or any agency thereof, or Battelle Memorial Institute. The views and opinions of authors expressed herein do not necessarily state or reflect those of the United States Government or any agency thereof.

\author{
PACIFIC NORTHWEST NATIONAL LABORATORY \\ operated by \\ BATTELLE \\ for the \\ UNITED STATES DEPARTMENT OF ENERGY \\ under Contract DE-AC05-76RL01830
}

Printed in the United States of America
Available to DOE and DOE contractors from the
Office of Scientific and Technical Information,
P.O. Box 62, Oak Ridge, TN 37831-0062;
ph: (865) 576-8401
fax: (865) 576-5728
email: reports@adonis.osti.gov

\author{
Available to the public from the National Technical Information Service, \\ U.S. Department of Commerce, 5285 Port Royal Rd., Springfield, VA 22161 \\ ph: (800) 553-6847 \\ fax: (703) 605-6900 \\ email: orders@ntis.fedworld.gov \\ online ordering: http://www.ntis.gov/ordering.htm
}

This document was printed on recycled paper. 


\title{
Radiation Doses to Hanford Workers from Natural Potassium-40
}

\author{
DJ Strom \\ TP Lynch \\ DR Weier
}

February 2009

Prepared for

the U.S. Department of Energy

under Contract DE-AC05-76RL01830

Pacific Northwest National Laboratory

Richland, Washington 99352 


\section{Summary}

The chemical element potassium is an essential mineral in people and is subject to homeostatic regulation. Natural potassium comprises three isotopes, ${ }^{39} \mathrm{~K},{ }^{40} \mathrm{~K}$, and ${ }^{41} \mathrm{~K}$. Potassium- 40 is radioactive, with a half life of 1.248 billion years. In most transitions, it emits a beta-minus particle with a maximum energy of $0.560 \mathrm{MeV}$, and sometimes a gamma photon of $1.461 \mathrm{MeV}$. Because it is ubiquitous, ${ }^{40} \mathrm{~K}$ produces radiation dose to all human beings. This report contains the results of new measurements of ${ }^{40} \mathrm{~K}$ in 248 adult females and 2,037 adult males performed at the Department of Energy Hanford Site in 2006 and 2007. Potassium concentrations diminish with age, are generally lower in women than in men, and decrease with body mass index $(B M I)$. The average annual effective dose from ${ }^{40} \mathrm{~K}$ in the body is 0.149 $\mathrm{mSv} \mathrm{y}^{-1}$ for men and $0.123 \mathrm{mSv} \mathrm{y}^{-1}$ for women, respectively. Averaged over both men and women, the average effective dose per year is $0.136 \mathrm{mSv} \mathrm{y}^{-1}$. Calculated effective doses range from 0.069 to 0.243 $\mathrm{mSv}^{-1}$ for adult males, and from 0.067 to $0.203 \mathrm{mSv} \mathrm{y}^{-1}$ for adult females, a roughly three-fold variation for each gender. The need for dosimetric phantoms with a greater variety of $B M I$ values should be investigated. From our data, it cannot be determined whether the potassium concentration in muscle in people with large $B M I$ values differs from that in people with small BMI values. Similarly, it would be important to know the potassium concentration in other soft tissues, since much of the radiation dose is due to beta radiation, in which the source and target tissues are the same. These uncertainties should be evaluated to determine their consequences for dosimetry. 



\section{Acronyms and Abbreviations}

\begin{tabular}{ll} 
Acronym & Meaning \\
\hline ANSI & American National Standards Institute \\
BMI & body mass index \\
BOMAB & Bottle Manikin Absorption \\
DF & dose factor \\
DOE & U.S. Department of Energy \\
$\dot{E}$ & effective dose rate \\
ICRU & International Commission on Radiation Units and Measurements \\
MBq & megabecquerel \\
MeV & megaelectronvolt \\
mGy & milligray \\
mSv & millisievert \\
NCRP & National Council on Radiation Protection and Measurements \\
PNNL & Pacific Northwest National Laboratory \\
RADAR & RAdiation Dose Assessment Resource \\
UNSCEAR & United Nations Scientific Committee on the Effects of Atomic Radiation
\end{tabular}





\section{Contents}

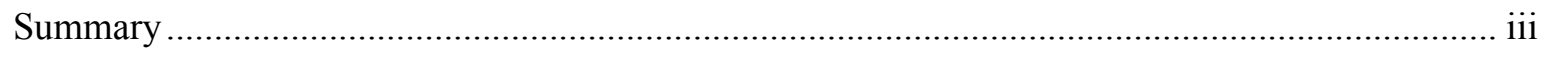

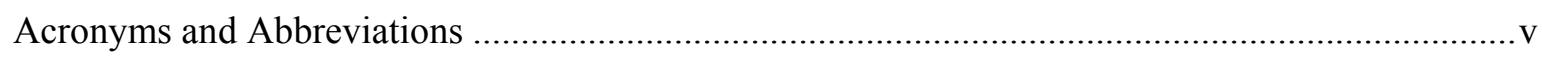

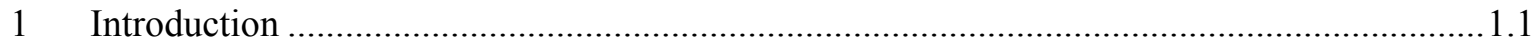

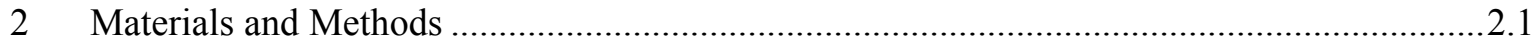

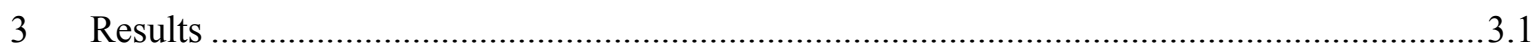

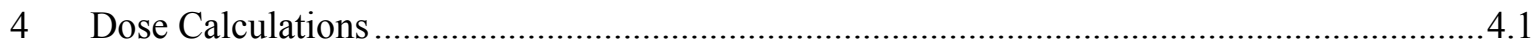

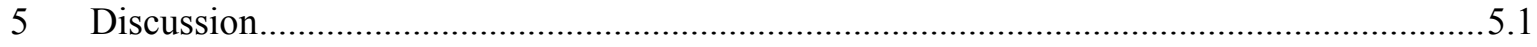

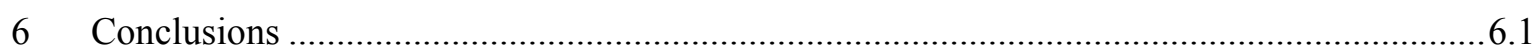

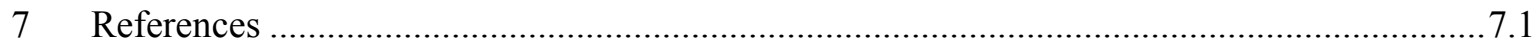




\section{Figures}

1. Counting geometry for PNNL's coaxial germanium scanning system...................................2.1

2. Five coaxial germanium detectors and electronics .................................................................2.2

3. Potassium concentration [K] (grams of potassium per kg of body mass) decreases with increasing age in adult women (left panel) and men (right panel). Dashed lines show upper and lower $95 \%$ confidence intervals for the population.

4. Potassium concentration [K] decreases with increasing body mass index $(B M I)$ in adult women (left panel) and men (right panel). Dashed lines show upper and lower 95\% confidence intervals for the populations

5. Effective dose per unit potassium concentration, $\mathrm{E} /[\mathrm{K}]$, as a function of body mass for the phantoms in Table 3.

6. Trends in age dependence of average ${ }^{40} \mathrm{~K}$ effective doses calculated using phantoms in Table 3 for males and females

\section{Tables}

1. Summary statistics for adult potassium measurements $[\mathrm{K}]$ (expressed as grams of potassium per kilogram of body mass) by gender, age, and body mass index (BMI).

2. Single and double linear regression results of potassium content as a function of gender, age, and body mass index (BMI).

3. Average dosimetric results using the dose factors (DF) from the RADAR site with Hanford potassium data for adult males and females. The adult female data were used for children...4.1 


\subsection{Introduction}

The chemical element potassium is an essential mineral in people and is subject to homeostatic regulation. Natural potassium comprises three isotopes, ${ }^{39} \mathrm{~K}(93.2581$ atom $\%),{ }^{40} \mathrm{~K}(0.0017$ atom \%), and ${ }^{41} \mathrm{~K}\left(6.7302\right.$ atom \%). Potassium-40 is radioactive, with a half life of $1.248 \times 10^{9} \mathrm{y}$. In $89.14 \%$ of transitions, it emits a $\beta^{-}$particle with a maximum energy of $0.560 \mathrm{MeV}$, and in $10.66 \%$ of transitions, it emits a gamma photon of $1.461 \mathrm{MeV}$.

Because it is ubiquitous, ${ }^{40} \mathrm{~K}$ produces radiation dose to all human beings.

In this report, we present the results of new measurements of ${ }^{40} \mathrm{~K}$ in Hanford workers, and analyze the dependence of potassium concentrations by age, sex, and body mass index. We report the results of past and present dose calculations, and make some recommendations for future research. 


\subsection{Materials and Methods}

The five coaxial germanium detectors shown in Figure 1 are part of a scanning system that is used to estimate the activity of fission products, activation products, and ${ }^{40} \mathrm{~K}$ in the body. The scanning system is located in a room with $30-\mathrm{cm}$ thick steel walls to create an environment with low levels of ambient background radiation. The inside surfaces of the steel are covered with thin layers of lead, cadmium, and copper to filter the Compton scattered photons and characteristic x-rays generated from photon absorption in the steel. The system is configured for scanning measurements, and Figure 2 shows the counting arrangement with the detector cryostats and Dewars mounted on a carriage that moves the detectors under the counting platform. The individual lies in a supine position on a foam pad on the 1.9-cm thick plastic platform during the 10-minute measurement. The detectors move from the head to the hips during the first nine minutes. The last minute is spent moving from the hips down the legs at a faster scan speed.

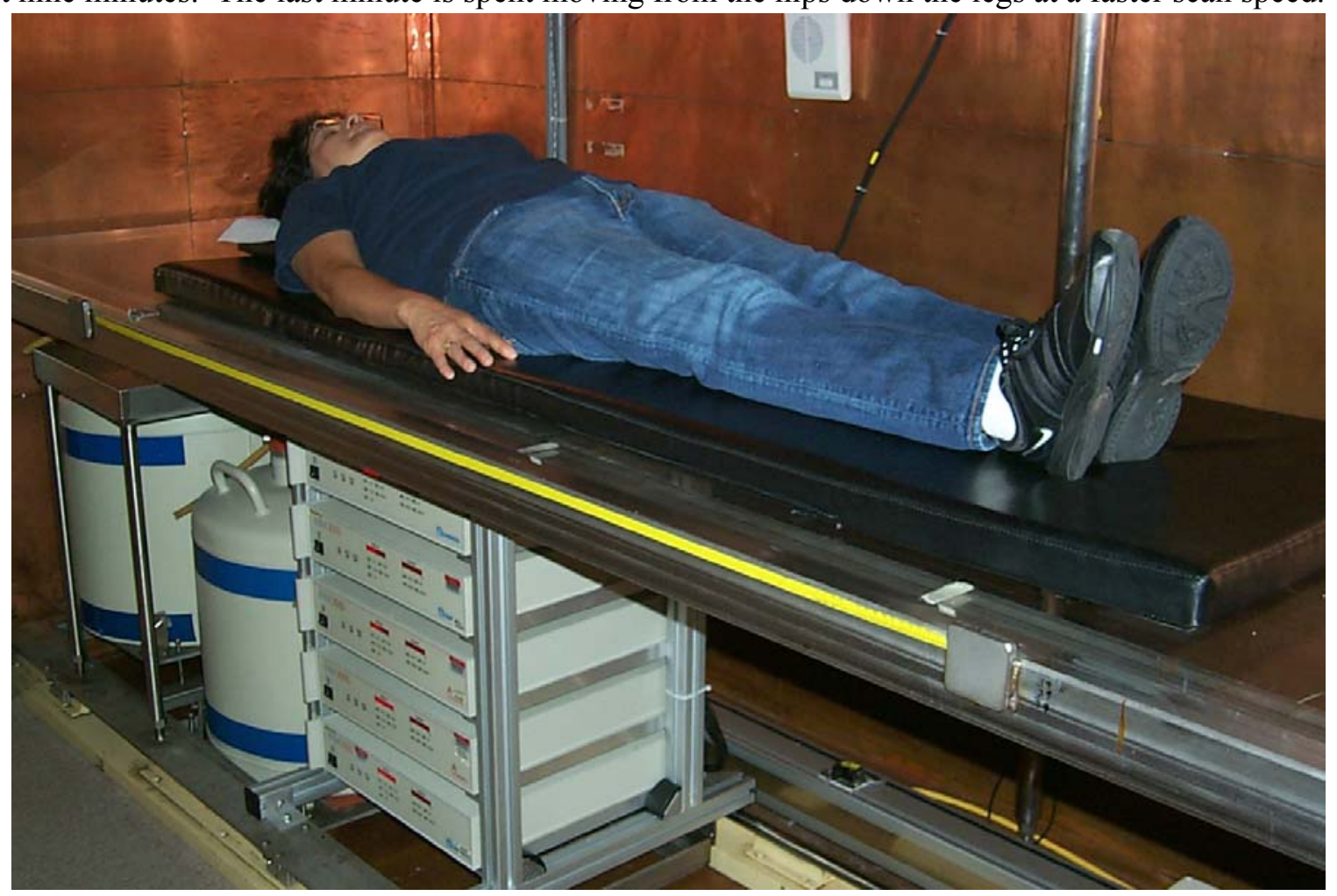

Figure 1. Counting geometry for PNNL's coaxial germanium scanning system 


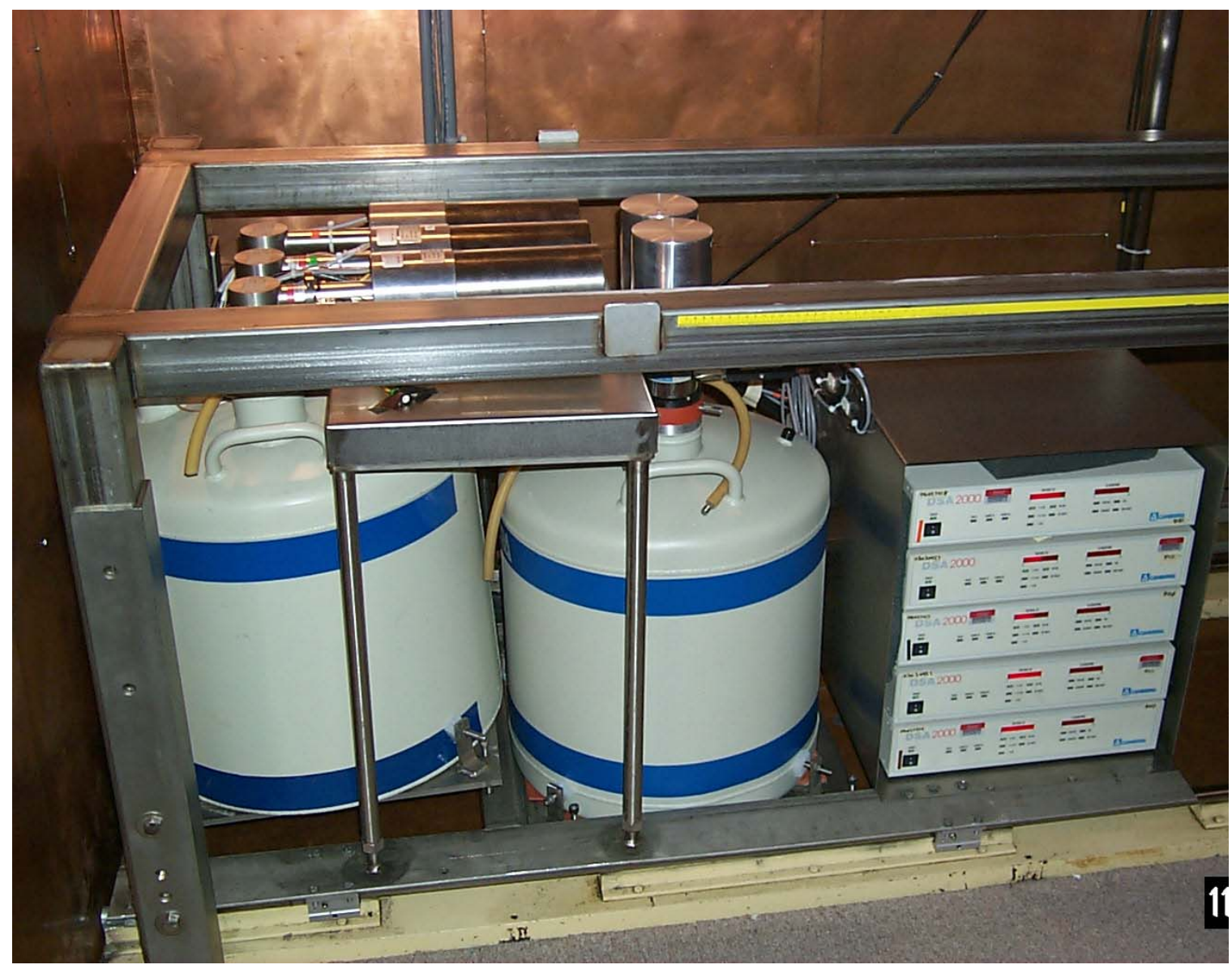

Figure 2. Five coaxial germanium detectors and electronics

The system is calibrated using Bottle Manikin Absorption (BOMAB) Phantoms (ANSI 1999). The phantom shell walls are composed of high density polyethylene. A solid polyurethane tissue-substitute with radiation attenuation characteristics matching average soft tissue (ICRU 1989) is used to fill the volume of each of the 10 sections. The polyurethane makes up most of the mass of the phantom. The ${ }^{40} \mathrm{~K}$ is uniformly distributed in the volume of polyurethane. The ${ }^{40} \mathrm{~K}$ activity is not traceable to the National Institute of Standards and Technology. The potassium was added in the form of $\mathrm{K}_{2} \mathrm{CO}_{3}$. The estimated uncertainty in the ${ }^{40} \mathrm{~K}$ activity in the phantom is $\pm 5 \%$.

The relative standard deviation for the ${ }^{40} \mathrm{~K}$ measurements is estimated as $10 \%$ based on 11 measurements performed on one adult male over a three-month period. Differences in activity distribution and size between an individual and the calibration phantom are additional sources of uncertainty and could result in an additional uncertainty of $10 \%$ to $20 \%$ in the measurement results. A longer counting time can be used to reduce the $4 \%$ to $5 \%$ uncertainty in the net count rate. 


\subsection{Results}

Fractional potassium concentration values $[\mathrm{K}]$, expressed as mass of potassium divided by body mass (g K/kg body mass or parts per thousand by mass), were calculated based on in vivo ${ }^{40} \mathrm{~K}$ measurements of 248 adult females and 2,037 adult males performed at the Department of Energy Hanford Site in 2006 and 2007. The potassium concentration in males is generally higher than the concentration in females due to a higher percentage of lean body mass in males. The average potassium concentration values decrease with age for both adult males and adult females as shown in Figure 3, as suggested by the United Nations Scientific Committee on the Effects of Atomic Radiation (UNSCEAR 1972) and quoted in (NCRP 1987). There are significant individual variations in potassium concentrations. The potassium concentration in males and females decreases with increasing values of body mass index (BMI) expressed as an individual's mass divided by the square of his or her height (in $\mathrm{kg} \mathrm{m}^{-2}$ ) as shown in Figure 4, again with significant individual variability about the population trend.
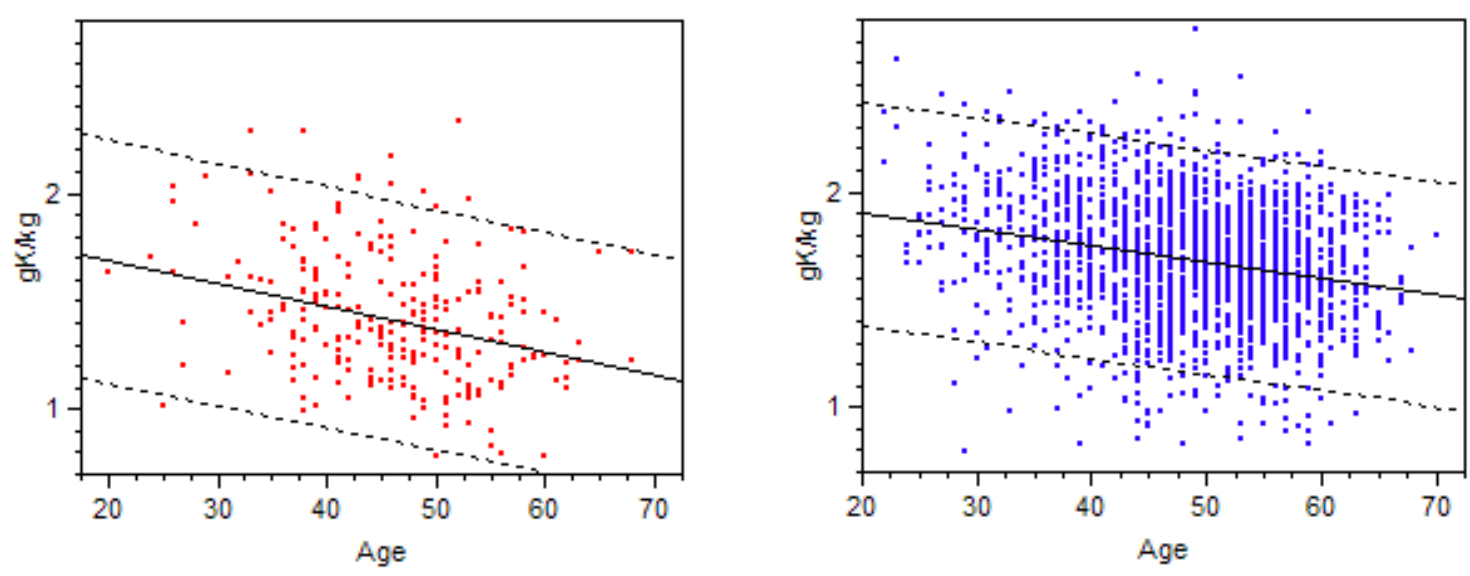

Figure 3. Potassium concentration $[\mathrm{K}]$ (grams of potassium per $\mathrm{kg}$ of body mass) decreases with increasing age in adult women (left panel) and men (right panel). Dashed lines show upper and lower $95 \%$ confidence intervals for the population. 

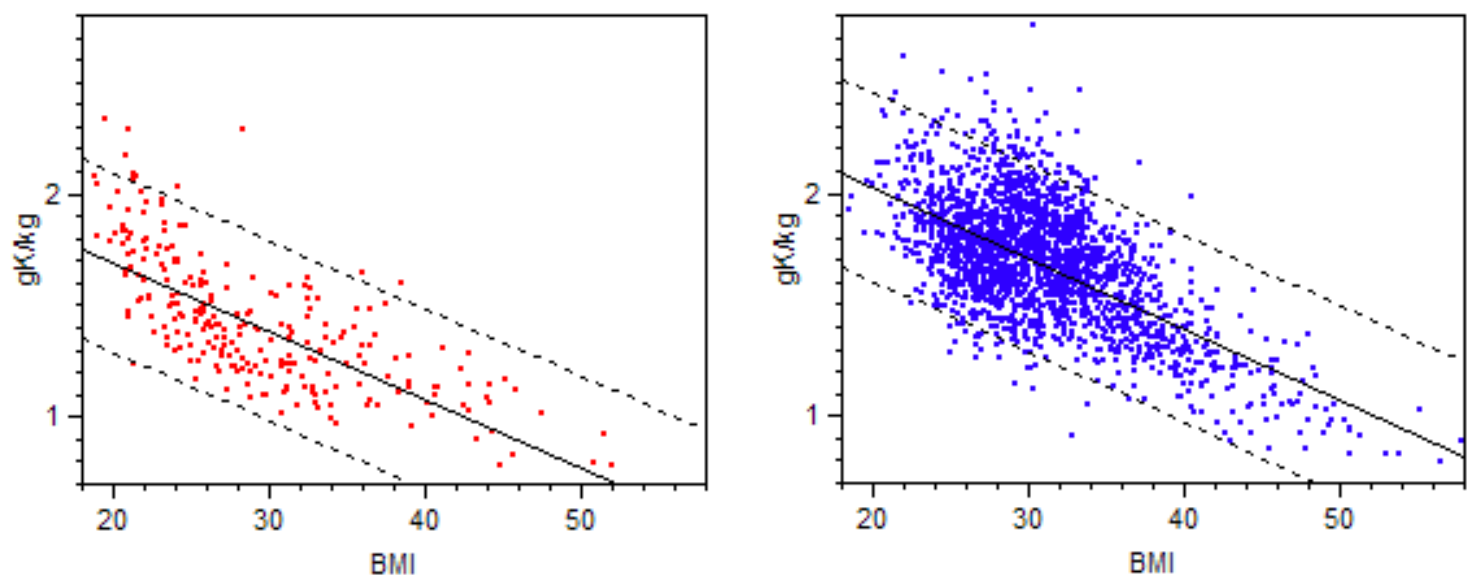

Figure 4. Potassium concentration $[\mathrm{K}]$ decreases with increasing body mass index $(B M I)$ in adult women (left panel) and men (right panel). Dashed lines show upper and lower 95\% confidence intervals for the populations.

Statistical properties of the data are given in Table 1 and Table 2. Data for males were more skewed to the right than a normal distribution, but less than a lognormal distribution. Data for females were lognormal.

Table 1. Summary statistics for adult potassium measurements [K] (expressed as grams of potassium per kilogram of body mass) by gender, age, and body mass index (BMI).

\begin{tabular}{lrrrrr}
\hline Gender & Number & $\begin{array}{r}\text { Average } \\
\left(\mathrm{g} \mathrm{kg}^{-1}\right)\end{array}$ & $\begin{array}{r}\text { Std. Dev. } \\
\left(\mathrm{g} \mathrm{kg}^{-1}\right)\end{array}$ & $\begin{array}{r}\text { Geo. Mean } \\
\left(\mathrm{g} \mathrm{kg}^{-1}\right)\end{array}$ & $\mathrm{S}_{\mathrm{G}}{ }^{\mathrm{a}}$ \\
\hline Males & 2037 & 1.682 & 0.273 & 1.66 & 1.187 \\
Females & 248 & 1.409 & 0.295 & 1.38 & 1.231 \\
\hline & & & & & \\
Gender & Parameter & Average & Std. Dev. & Minimum & Maximum \\
\hline Males & Age (y) & 48.8 & 8.58 & 22 & 70 \\
Females & Age (y) & 46.1 & 8.56 & 20 & 68 \\
Males & BMI $\left(\mathrm{kg} \mathrm{m}^{-2}\right)$ & 30.9 & 5.32 & 18.5 & 57.8 \\
Females & BMI $\left(\mathrm{kg} \mathrm{m}^{-2}\right)$ & 29.2 & 6.96 & 18.9 & 52.1 \\
\hline
\end{tabular}

${ }^{\mathrm{a}} s_{\mathrm{G}}$ denotes geometric standard deviation.

Table 2. Single and double linear regression results of potassium content as a function of gender, age, and body mass index $(B M I)$. 


\begin{tabular}{lrrrrr}
\hline Gender & $\begin{array}{r}\text { Intercept } \\
\left(\mathrm{g} \mathrm{kg}^{-1}\right)\end{array}$ & $\begin{array}{r}\text { Slope: Age } \\
\left(\mathrm{g} \mathrm{kg}^{-1} \mathrm{y}^{-1}\right)\end{array}$ & $\begin{array}{r}\text { Slope: } B M I \\
\left(\mathrm{~g} \mathrm{~kg}^{-1}\left(\mathrm{~kg} \mathrm{~m}^{-2}\right)^{-1}\right)\end{array}$ & $r^{2}$ & $\begin{array}{r}\text { Geometric } \\
\text { Standard } \\
\text { Deviation } \\
\mathrm{S}_{\mathrm{G}}{ }^{\mathrm{a}}\end{array}$ \\
\hline Males & 2.664 & & -0.0318 & 0.384 & \\
Females & 2.306 & & -0.0307 & 0.524 & \\
Males & 2.047 & -0.00747 & & 0.055 & \\
Females & 1.897 & -0.01058 & & 0.094 & \\
Males & 2.946 & -0.00620 & -0.0311 & 0.421 & 1.133 \\
Females & 2.500 & -0.00512 & -0.0292 & 0.544 & 1.148 \\
\hline
\end{tabular}

${ }^{\mathrm{a}}$ The individual variation from the value predicted by these equations is lognormally-distributed about the arithmetic mean with this geometric standard deviation. The geometric mean of the lognormal distribution is equal to the arithmetic mean multiplied by $e^{-\left(\ln S_{\mathrm{G}}\right)^{2 / 2}}$ (Strom and Stansbury 2000). 


\subsection{Dose Calculations}

Dosimetry was performed from first principles as well as using the methods of Stabin and Siegel (2003). Standard phantoms were used from Cristy and Eckerman (1987) with the addition of the adult female phantom of Stabin and Siegel (2003).

Radioactive ${ }^{40} \mathrm{~K}$ emits an $0.56 \mathrm{MeV}$ average energy beta particle in $89.14 \%$ of transitions, and a 1.46 $\mathrm{MeV}$ photon in $10.66 \%$ of transitions (National Nuclear Data Center 2007). With a ${ }^{40} \mathrm{~K}$ fractional abundance of 0.0117 atom \% or 0.01196 mass \% (NNDC 2007), natural potassium has a specific activity of $31.72 \mathrm{~Bq} \mathrm{~g}^{-1}$. The possible energy per transition that can be absorbed ranges from $8.00 \times 10^{-14} \mathrm{~J}$ if none of the $1.46 \mathrm{MeV}$ photons are absorbed to $10.50 \times 10^{-14} \mathrm{~J}$ if all of those photons are absorbed. In the 1987 Report, NCRP appears to have used an absorbed fraction of 0.8 (National Council on Radiation Protection and Measurements (NCRP) 1987).

Using "dose factors" (DFs; $\mathrm{mGy} \mathrm{MBq}^{-1} \mathrm{~s}^{-1}$ ) for ${ }^{40} \mathrm{~K}$ in seven different phantoms from the RADAR web site (Stabin et al. 2008) and the Hanford age- and gender-dependent potassium data, yields the results in Table 3. The dose factors were for uniform whole body sources irradiating the whole body. On average, adult males have $19 \%$ more potassium per unit body mass compared to women, and receive $21 \%$ more absorbed dose. Of the $21 \%$ greater absorbed dose, $19 \%$ is due to the greater potassium concentration in men, while the remaining $2 \%$ is due to the increased absorption of the $1.46 \mathrm{MeV}$ photon.

Table 3. Average dosimetric results using the dose factors (DF) from the RADAR site with Hanford potassium data for adult males and females. The adult female ${ }^{40} \mathrm{~K}$ data were used for children.

\begin{tabular}{|c|c|c|c|c|c|c|c|c|}
\hline Phantom & & $\begin{array}{r}D F\left(\mathrm{mGy}^{-1}\right. \\
\mathrm{MBq}^{-1} \\
\left.\mathrm{~s}^{-1}\right)\end{array}$ & $\begin{array}{l}\text { Phantom } \\
\text { Mass (g) }\end{array}$ & $\begin{array}{c}{[\mathrm{K}](\mathrm{g}} \\
\mathrm{kg})^{-1}\end{array}$ & $\begin{array}{r}{ }^{40} \mathrm{~K} \\
\text { activity } \\
\text { per unit } \\
\text { body } \\
\text { mass } \\
(\mathrm{Bq} \\
\left.\mathrm{kg}^{-1}\right)\end{array}$ & $\begin{array}{r}{ }^{40} \mathrm{~K} \\
\text { activity } \\
\text { in the } \\
\text { body } \\
(\mathrm{Bq})\end{array}$ & $\begin{array}{r}\text { Annual } \\
{ }^{40} \mathrm{~K} \text { trans- } \\
\text { itions } \\
\left(\begin{array}{c}\mathrm{MBq} \mathrm{S}^{-1} \\
\left.\mathrm{y}^{-1}\right)\end{array}\right.\end{array}$ & $\begin{array}{r}\text { Annual } \\
\text { Abs. } \\
\text { Dose } \\
\left(\mathrm{mGy}^{-1}\right) \\
\left.\mathrm{y}^{-1}\right)\end{array}$ \\
\hline$C \& E^{a}$ & Adult Male & $1.20 \mathrm{E}-06$ & 73,700 & 1.682 & 53.36 & 3,933 & $1.24 \mathrm{E}+05$ & 0.149 \\
\hline$S \& S^{b}$ & Adult Female & $1.54 \mathrm{E}-06$ & 56,800 & 1.409 & 44.70 & 2,539 & $8.01 \mathrm{E}+04$ & 0.123 \\
\hline$C \& E^{a}$ & 15-yr-old & $1.54 \mathrm{E}-06$ & 56,800 & 1.409 & 44.70 & 2,539 & $8.01 \mathrm{E}+04$ & 0.123 \\
\hline$C \& E^{a}$ & 10 -yr-old & 2.61E-06 & 33,200 & 1.409 & 44.70 & 1,484 & $4.68 \mathrm{E}+04$ & 0.122 \\
\hline$C \& E^{a}$ & 5-yr-old & $4.35 \mathrm{E}-06$ & 19,800 & 1.409 & 44.70 & 885 & $2.79 \mathrm{E}+04$ & 0.122 \\
\hline$C \& E^{a}$ & 1-yr-old & $8.76 \mathrm{E}-06$ & 9,720 & 1.409 & 44.70 & 435 & $1.37 \mathrm{E}+04$ & 0.120 \\
\hline$C \& E^{a}$ & Newborn & $2.33 \mathrm{E}-05$ & 3,600 & 1.409 & 44.70 & 161 & $5.08 \mathrm{E}+03$ & 0.118 \\
\hline
\end{tabular}

${ }^{\mathrm{a}} \mathrm{C} \& \mathrm{E}$ - Cristy and Eckerman (1987)

${ }^{\mathrm{b}} \mathrm{S} \& \mathrm{~S}-$ Stabin and Siegel (2003).

None of the phantoms currently incorporate a variable body mass index. The adult male phantom has a BMI of 26.43, compared to the Hanford male average of 30.9. The absorbed fraction will be somewhat higher in bodies with higher BMI. The dose factor approach is consistent with a first-principles approach assuming an absorbed fraction of about 0.34 for the $1.46 \mathrm{MeV}$ photon. 
Figure 5 shows a modest increase in the effective dose with body mass, primarily due to increased absorption of the $1.46 \mathrm{MeV}$ photon as mass increases.

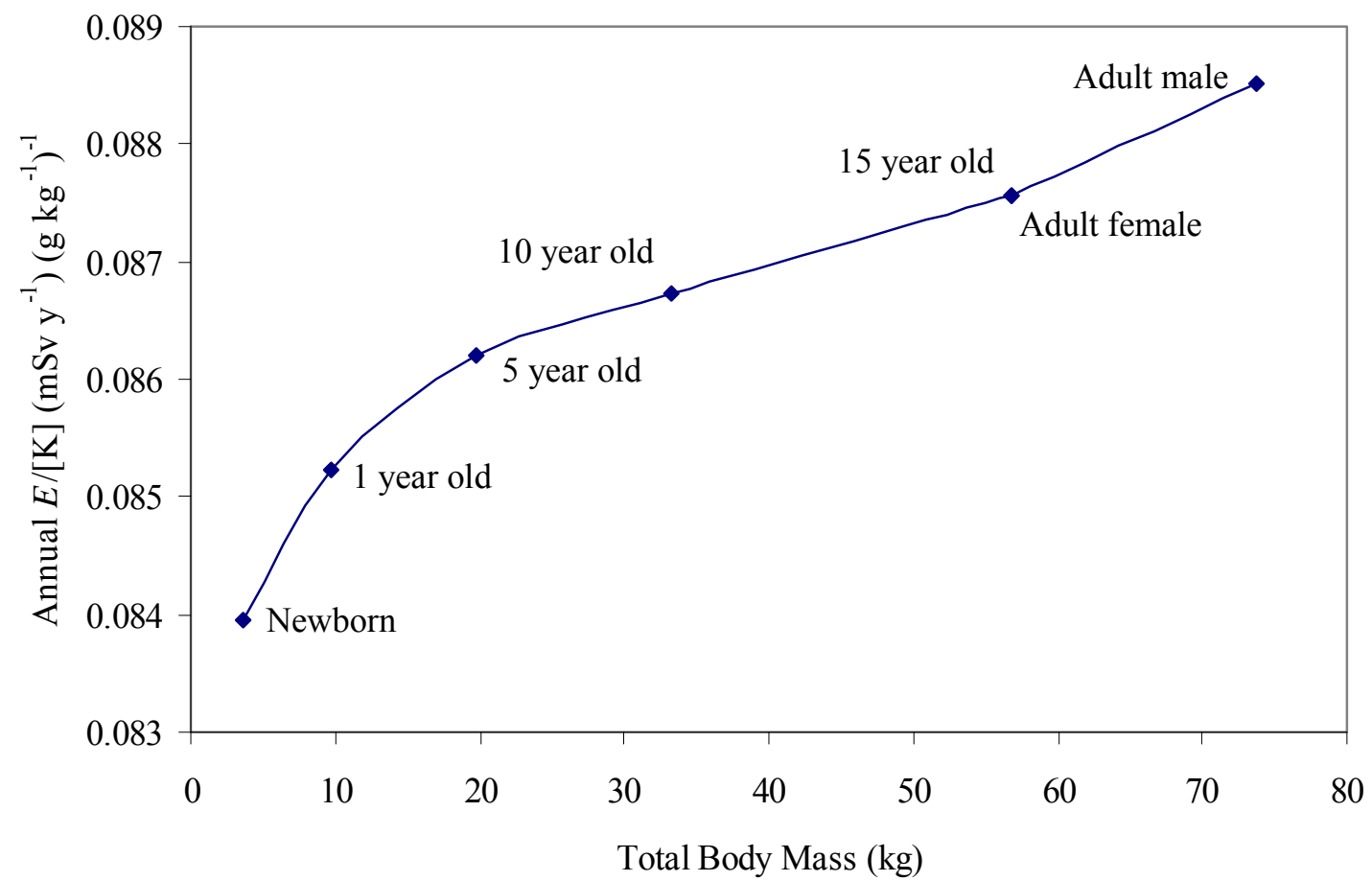

Figure 5. Effective dose per unit potassium concentration, $\mathrm{E} /[\mathrm{K}]$, as a function of body mass for the phantoms in Table 3.

Trends in age dependence of average ${ }^{40} \mathrm{~K}$ effective doses calculated using phantoms in Table 3 for males and females are shown in Figure 6 for the data from NCRP (1987) and for the Hanford data. Doses to adult males are about $8 \%$ lower at Hanford, probably due at least in part to the decreased ${ }^{40} \mathrm{~K}$ concentrations associated with the higher average BMI of Hanford males. Doses to adult males are higher than those to adult females by an average of $32 \%$ in the NCRP data and $22 \%$ in the Hanford data. 


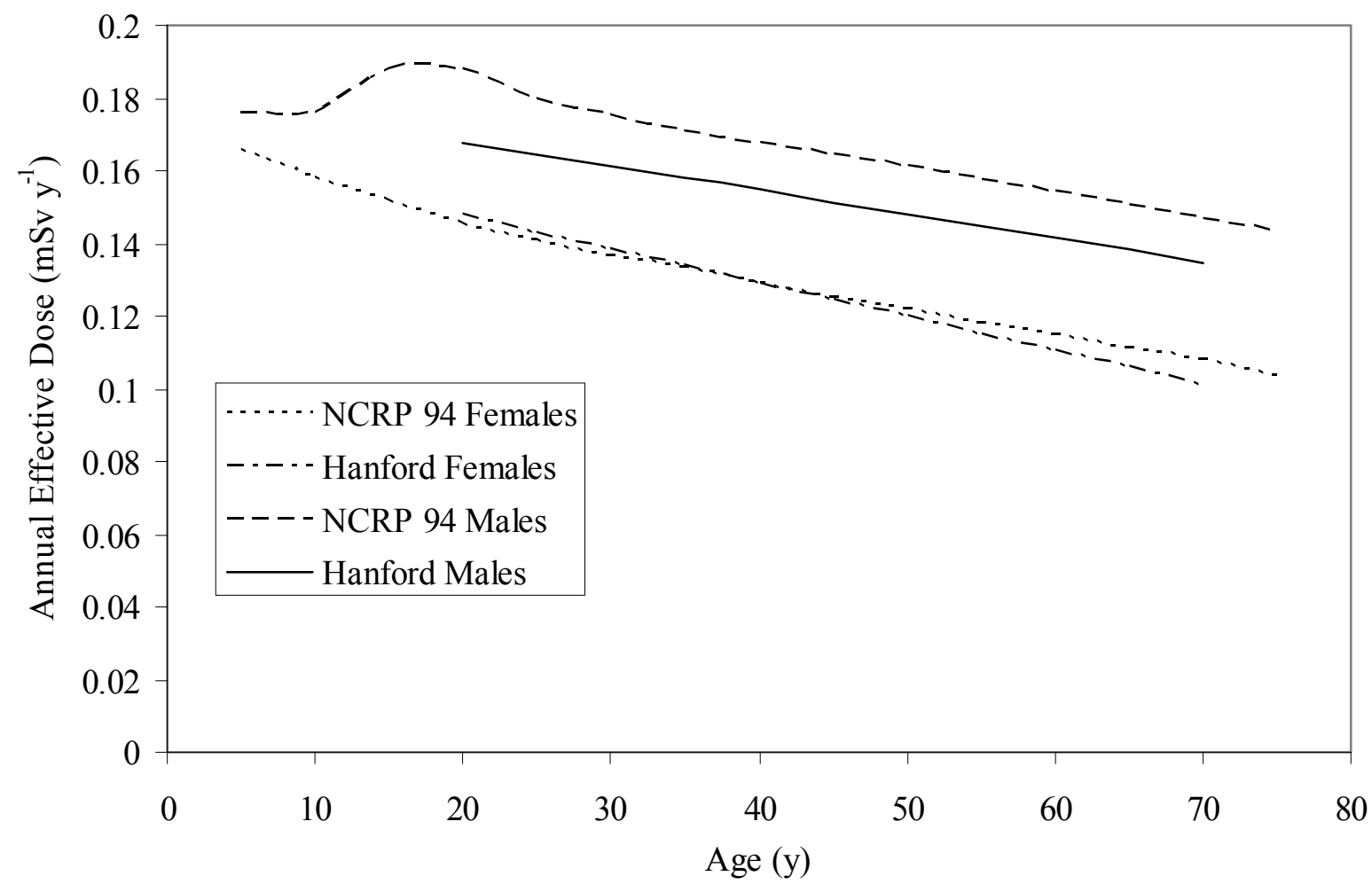

Figure 6. Trends in age dependence of average ${ }^{40} \mathrm{~K}$ effective doses calculated using phantoms in Table 3 for males and females 


\subsection{Discussion}

Significant data on potassium concentrations are unavailable for people under 20 years of age. Their lower body mass would result in a somewhat lower dose for a given potassium concentration, due to the greater escape probability of the $1.46 \mathrm{MeV}$ photon. Data on potassium concentrations in young people are needed.

The decreasing mass fractions of potassium with BMI are not easily interpreted from the point of view of relevant dosimetry. Despite the data shown in Table 7.7 of NCRP Report No. 94 (1987), adequate data are not available on the distribution of potassium in organs and tissues of overweight or obese people. In particular, the Hanford data on an American worker population beg the question of whether lowered average potassium concentrations in persons with higher BMI indicate a lowered dose to tissues in which deposition of ionizing radiation energy causes detriment. Research focusing on dosimetry of alkali metals such as potassium and cesium as a function of BMI or other indicators is needed. The importance of dose to adipose or otherwise fatty tissues is not explicitly addressed in the literature. It is simply unknown what the importance of average alkali metal (e.g., ${ }^{40} \mathrm{~K}$ or ${ }^{137} \mathrm{Cs}$ ) dose is in persons with a BMI that differs significantly from the phantoms described by Cristy and Eckerman (1987) or Stabin and Siegel (2003).

In summary, the ubiquitous naturally-occurring radionuclide ${ }^{40} \mathrm{~K}$ produces radiation doses that have significant trends with sex, age, body mass, and body mass index, with significant individual variability. The annual effective dose for average adult males as a function of age and BMI is

$$
\dot{E}_{\text {Average Adult Male }}=\frac{0.0885 \mathrm{mSv} \mathrm{y}^{-1}}{\mathrm{~g} \mathrm{~kg}^{-1}}\left(2.946-0.00620\left(\mathrm{y}^{-1}\right) A g e(\mathrm{y})-0.0311\left(\mathrm{~m}^{2} \mathrm{~kg}^{-1}\right) B M I\left(\mathrm{~kg} \mathrm{~m}^{-2}\right)\right)\left(\mathrm{g} \mathrm{kg}^{-1}\right)
$$

and for average adult females is

$$
\dot{E}_{\text {Average Adult Female }}=\frac{0.0876 \mathrm{mSv} \mathrm{y}^{-1}}{\mathrm{~g} \mathrm{~kg}^{-1}}\left(2.500-0.00512\left(\mathrm{y}^{-1}\right) \operatorname{Age}(\mathrm{y})-0.0292\left(\mathrm{~m}^{2} \mathrm{~kg}^{-1}\right) B M I\left(\mathrm{~kg} \mathrm{~m}^{-2}\right)\right)\left(\mathrm{g} \mathrm{kg}^{-1}\right) \text {. }
$$

Individual variability about these arithmetic mean values is described by a lognormal distribution with a geometric standard deviation $s_{\mathrm{G}}$ of 1.133 for males and 1.148 for females. The geometric means of these lognormal distributions are equal to the arithmetic means multiplied by $e^{-\left(\ln S_{\mathrm{G}}\right)^{2} / 2}$ (Strom and Stansbury 2000). 


\subsection{Conclusions}

The average annual effective dose from ${ }^{40} \mathrm{~K}$ in the body is $0.149 \mathrm{mSv} \mathrm{y}^{-1}$ for men and $0.123 \mathrm{mSv} \mathrm{y}^{-1}$ for women, respectively. Averaged over both men and women, the average effective dose per year is $0.136 \mathrm{mSv} \mathrm{y}^{-1}$. Effective doses range from 0.069 to $0.243 \mathrm{mSv} \mathrm{y}^{-1}$ for adult males, and 0.067 to 0.203 $\mathrm{mSv}^{-1}$ for adult females, a roughly three-fold variation for each gender.

Given the fact that there are many people with larger body mass index at Hanford than is used in current dosimetric phantoms, the need for dosimetric phantoms with a greater variety of $B M I$ values should be investigated.

From our data, it cannot be determined whether the potassium concentration in muscle in people with large $B M I$ values differs from that in people with small BMI values. Similarly, it would be important to know the potassium concentration in other soft tissues, since much of the radiation dose is due to beta radiation, in which the source and target tissues are the same. These uncertainties should be evaluated to determine their consequences for dosimetry. 


\subsection{References}

American National Standards Institute (ANSI). 1999. Specifications for the Bottle Manikin Absorption Phantom. An American National Standard. ANSI/HPS N13.35-1999, Health Physics Society, McLean, Virginia.

Cristy M and KF Eckerman. 1987. Specific absorbed fractions of energy at various ages from internal photons sources. ORNL/TM-8381 V1-V7, Oak Ridge National Laboratory, Oak Ridge, Tennessee.

International Commission on Radiation Units and Measurements (ICRU). 1989. Tissue Substitutes in Radiation Dosimetry and Measurement. ICRU Report No. 44, ICRU Publications, Bethesda, Maryland.

National Council on Radiation Protection and Measurements (NCRP). 1987. Exposure to the Population in the United States and Canada from Natural Background Radiation. Report No. 94, NCRP

Publications, Bethesda, Maryland.

National Nuclear Data Center. 2007. Chart of Nuclides.

http://www.nndc.bnl.gov/chart/reCenter.jsp? $\mathrm{z}=19 \& \mathrm{n}=21$ and

http://www.nndc.bnl.gov/chart/decaysearchdirect.jsp?nuc=40K\&unc=nds accessed Feb. 15, 2008.

Brookhaven National Laboratory, Upton, New York.

Stabin MG and JA Siegel. 2003. "Physical models and dose factors for use in internal dose assessment." Health Physics 85(3):294-310.

Stabin MG, JA Siegel, RB Sparks, DJ Buchsbaum, KF Eckerman, J Hunt, CS Marcus, and XG Xu. RADAR - Available Phantoms. http://www.doseinfo-radar.com/RADARphan.html accessed Feb. 15, 2008. The RADAR Team.

Strom DJ and PS Stansbury. 2000. "Determining Parameters of Lognormal Distributions from Minimal Information. PNNL-SA-32215." American Industrial Hygiene Association Journal 61(Nov-Dec):877-880.

United Nations Scientific Committee on the Effects of Atomic Radiation (UNSCEAR). 1972. Ionizing Radiation: Levels and Effects. A report of the United Nations Scientific Committee on the Effects of Atomic Radiation to the General Assembly, with annexes.

http://www.unscear.org/unscear/en/publications/1972.html, United Nations, Vienna. 
PNNL 18240

\section{Distribution}

No. of

Copies

1 Anthony C. James

United States Transuranium and

Uranium Registries

1845 Terminal Drive

Richland, WA 99354

1 Michael G. Stabin

Vanderbilt University

Department of Radiology and

Radiological Sciences

116121 st Avenue South

Nashville, TN 37232-2675

1 Marvin Rosenstein

National Council on Radiation

Protection and Measurements

7910 Woodmont Avenue, Suite 400

Bethesda, MD 20814-3095

1 Thomas S. Tenforde

National Council on Radiation

Protection and Measurements

7910 Woodmont Avenue, Suite 400

Bethesda, MD 20814-3095
No. of

Copies

\section{Local Distribution}

Pacific Northwest National Laboratory

Mark S. Hanson

K9-09

Michelle L. Johnson

P7-01

Wayne L. Johnson 



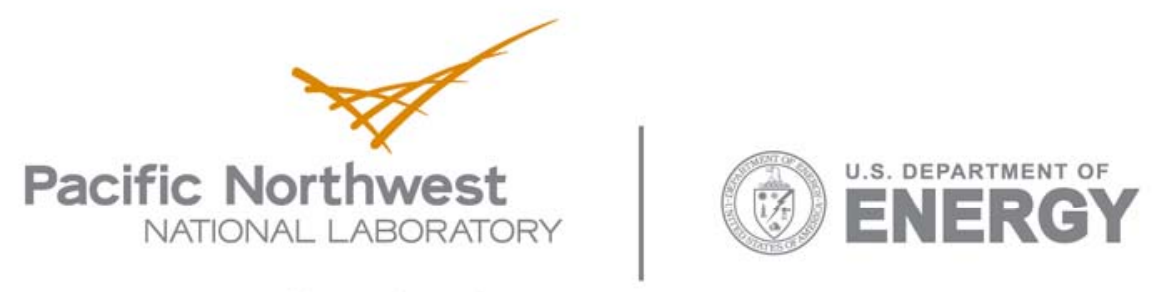

902 Battelle Boulevard

P.O. Box 999

Richland, WA 99352

1-888-375-PNNL (7665)

www.pnl.gov 